cocomatonaraty

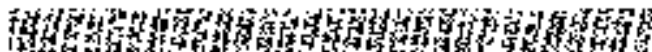

mand

H

13

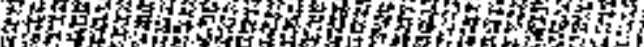

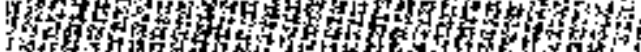

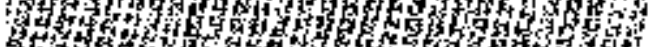

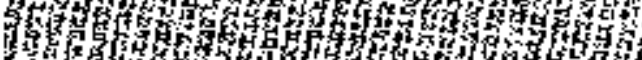

1.

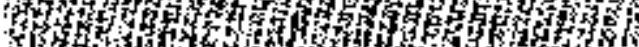

Hot 34 H

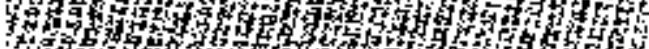

of

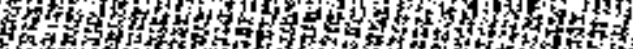

ग)

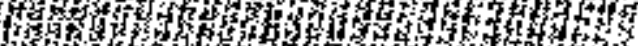

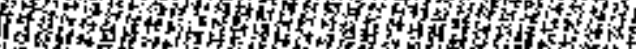

a h

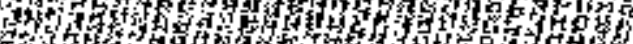

a

13

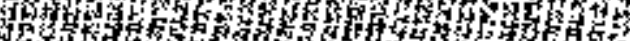

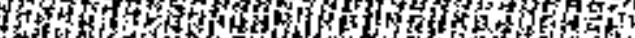
I

1. 3y

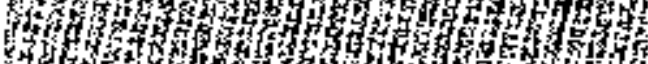

S3

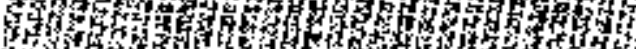

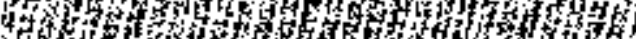

45 w

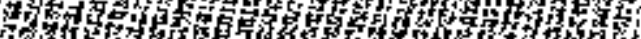

W U 3 \%

治

H.

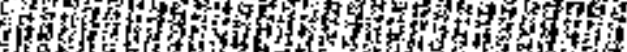

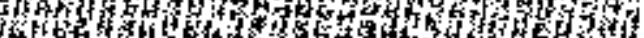

43 kno

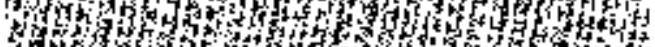

49.

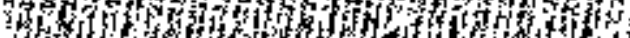

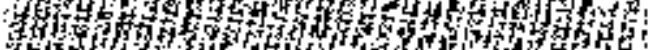

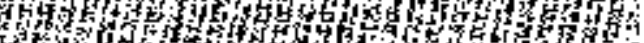
7y W ( m3

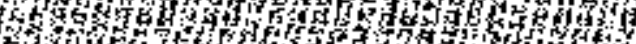

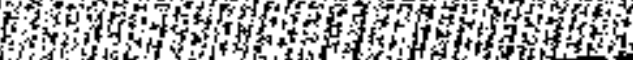

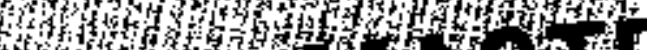

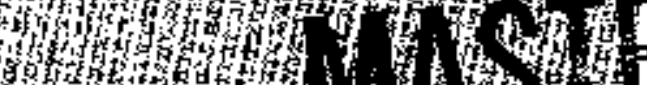
Bing

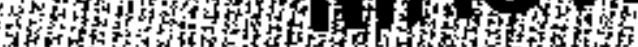
건

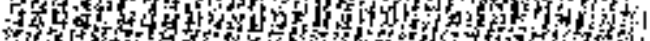

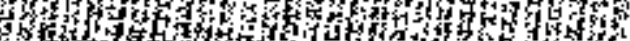

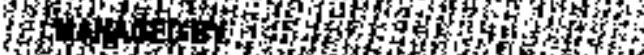

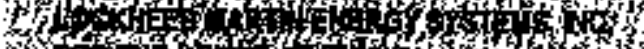

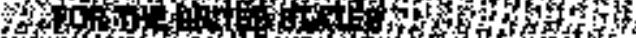

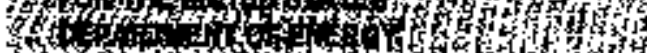
wh

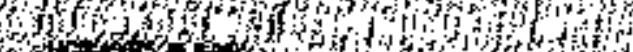

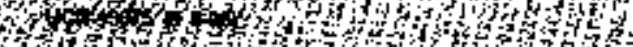

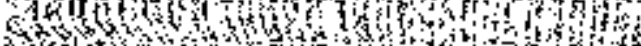

Y/FN-5492

\author{
Masonry Infill Performance During the \\ Northridge Earthquake
}

\section{RECEIVED JAN 038997 O\&TI}

March 8, 1996

For Presentation at the

1996 North American Masoary Conference South Bend, Indiana

\author{
Oak Ridge Y-12 Plant
}

Oak Ridge, Tennessee 37831 managed by

Lockheed Martin Energy Systems, Inc. for the U.S. DEPARTMENT OF ENERGY under contract DE-AC05-840R21400 


\section{DISCLAIMEA}

This report way prepared as an account of work sponsored by an anenty of the United Status Gowernment. Meither the Uniled States Gowtinment nor any agency therefi, nor ony of their employees, mekes any warranty, oxpress ar impliad, ar usstmes any legal labulty of reponsibility lor the accurdey, completenos, $\alpha$ use. fulnass of any information, apperstus, product, or protess diaclosed, or reprents that its use would not infrings privately awned rights. Reforance harain to amy spacific commerio product, process, or service by trade name, trademark, mantfacturar, or stherwise, doss nat necesserily constitute or impty its andoranent, recommendation, ar foworting by the Unitod \$ta1sa Gowarnmant or amy aponcy thereof. The views and apinions of authors expressed herein ob not necestarly state or reflect those of the United States Govemment of any ausncy thereof.

\section{COPYRIGHT NOTICE}

The subaritted mantuscript has been authored by a contractior of the v.S. Govemneat under contract DE-AC05-84OR21400. Accordingly, the U.S. Government teains a paidelp, nonexclusive, intovocable, warkiwite license to publisb or reproduce the published form of this conkribution. prepare derivative works, distriate copies to the public, and perfont publicly anki display publicly, or nlkow others to do so, for U.S. Government purposes. 


\title{
MASONRY INFILL PERFORMANCE DURING THE NORTHRIDGE EARTHQUAKE
}

\author{
by Roger D. Flanagan', Richard M. Bennett', Samy A. Adhamn ${ }^{3}$ William L. Fischer ${ }^{4}$
}

\begin{abstract}
The response of masonry infills during the 1994 Northridge, California earthquake is described in terms of three categories; (1) lowrise and midrise structures experiencing large near field seismic excitation, (2) lowrise and midrise structures experiencing moderate far field excitation, and (3) highrise struchures experiencing moderate far field excitation. In general, the infills provided a positive beneficial effect on the performance of the buildings, even those experiencing large peak accelerations near the epicenter. Varying types of masonry infills, structural frames, design conditions, and construction deficiencies were observed and their performance during the earthquake indicated. A summary of observations of the perfornance of infills in other tecent earthquakes is given. Comparison with the Northridge earthquake is made and expected response of infill stnuctures in lower seismic regions of the central and eastern United States is discussed.
\end{abstract}

KEYWORDS: Masonry, Infills, Northridge Earthquake, Brick, Concrete Masonry, Clay Tile

Manager, Advanced Technology Department, Lockheed Martin Energy Systems, Oak Ridge, TN 37831-8201, USA

2 Professor of Civil and Environmental Engineting, The University of Tennessee, Knoxville, TN 37996-20]0, USA

3 Associate, Agbabian Associates, Pasadena, CA 91105, USA

4 The University of Tennessee, Knox ville, TN 37996-2010, USA 


\section{DISCLAIMER}

Portions of this document may be iflegible in electronic image products. Images are produced from the best available original document. 


\section{INTRODUCTION}

A series of field observations were made of the performance of masonry infitled frame structures in the January 17, 1994 Northridge, Califoria earthquake. The earthquake originated in Northridge approximately $30 \mathrm{~km}$ west northwest of downtown Los Angeles. The earthquake occurred in a concealed fault of the San Fernando valley at depths of 19 to $7 \mathrm{~km}$. The moment magnitude for the earthquake was $M_{w} 6.7$ (Wald and Heaton, 1994). Although the fieid observations were made well after the earthquake occurred, none of the structures had undergone any significant structural alterations since the earthquake.

The performance of infill structures is described in terms of building height and relative location to the earthquake epicenter. Varying types of masonry infills, structural frames, design conditions, and construction deficiencies were investigated. A summary of observations of the performance of infills in other recent earthiguakes is given. Comparison with the Northridge earthquake is made and expected response of infill structures in lower seistnic regions of the central and eastern United States is discussed.

\section{NEAR FIELD EXCITATION: LOWRISE \& MIDRISE STRUCTURES}

Several notable examples of double wythe reinforced clay brick infills existed near the epicenter of the Northridge Earthquake. Among these were the Cal State Northridge Dormitory, and Buildings 3 and 40 at the Sepulveda Veterans Administration Hospital (TMS, 1994). Typical construction was a $91 / 2^{n}$ wall consisting of two $31 / 2^{n}$ clay brick wythes, and a $2 t / 2$ " grout space containing the reinforcing. The exterior wythe was typically outside the structural framing. Damage was observed in all these buildings. Part of the damage appeared to be typical infill damage, consisting of diagonal cracking and corner cnushing. In several cases, the outer wythe appeared to have been inadequately tied to the interior wythe.

Building 40 at the Sepulveda VA hospital is a one story steam plant building with a reinforced concrete frame, Figure 1 . Records at the base showed peak accelerations of $0.75 \mathrm{~g}$ in the east-west direction, $0.94 \mathrm{~g}$ in the north-south direction, and $0.45 \mathrm{~g}$ in the vertical direction. This building was constructed in 1955. It appeared well designect, but some construction deficiencies were apparent. Concrete had spalled off of one concrete column near the base revealing about 15 " of vertical reinforcing, Figure 2 . No ties were present in this length, despite plans calling for \#3 ties at $10^{n}$. There was also a comer of the infill that had been damaged revealing the grout core, Figure 3. One place was observed in which there was a large void in the grout leaving some rejnforcing with no grout around it. Nevertheless, this building survived the large ground shaking to which it was subjected. The building had visible damage at numerous locations but did not suffer collapse. Therefore, life safety was achieved and the building still has limited use. However, it will eventually be replaced. The infills had a positive beneficial effect on the performance of this structure. 


\section{FAR FIELD EXCITATION: LOWRISE \& MIDRISE STRUCTURES}

Several parking garages in the northern Los Angeles area were observed which had reinforced concrete frames with concrete masoniry infills. In one instance, these were separated from the concrete frame by a $1 / 2 "-1$ " joint filled with stytofoam, Figures 4-5. Obviously the intent was to isolate the infill from the frame, so that there would be no interaction. Isolating the infill leads to other problems. The infill must be adequately anchored out-of-plane, as arching cannot develop. If the gap is not lasge enough, the columns will engage the infilk, and it will interact with the structure (Flanagan, 1994). Yanev and McNiven (1985) observed in dynamic testing that the buffeting that occurs when the frame engages the infill quickly destroys the infill. They tried using foam rubber as a filler in the gap to minimize the impact effects, but it had minimal effect. Thus, in designing isolated infills, the out-of-plane anchorage and the provision of a sufficient gap ( $1 / 2$ " may be inadequate since it only allows for approxinately $0.5 \%$ drift) need to be considered.

Other parking garages were observed which had concrete masonry infills tightly fitted against the framing, Figure 6. These would then form part of the lateral load resisting system, and may have limited danage, or in some cases prevented coltapse. Figure 7 shows an infill where there was cracking around the infill perimeter and some cracking in the concrete frame. One parking garage was observed which had out-of-plane supports at the top of a tightly fitted infill consisting of large steel angles anchored to the infill and underside of the beam. In terms of resisting out-of-plane motions, the angles were superfluous, as the anching capacity would greatly exceed the capacity of the angles. At most, only a nominal connection would be needed to insure the initiation of arching, and the prevention of walking of the infill. Cracking was noted around the anchors from in-plane movements. Dawe and Seah (1989) observed in experimental testing that ties between a steel colurnn and a concrete masonry infill actually slightly rectuced the in-plane capacity. The ties resulted in extensive off-diagonal random cracking of the infill, and prevented the compression diagonal from fully developing. Presumably, anchors at the top would have the same effect, and possibly more drastic. If the angles caused premature failure of the upper course of the infill, the behavior would be simitar to a infill with a top gap. This leads to significantly lower capacities, and the increased likelihood of shear failures in the columns. It is thus believed that out-of-plane anchors of tightly fitted infills may do more harm than good, and are not necessary.

\section{FAR FIELD EXCITATION: HIGHRISE STRUCTURES}

Several buildings in downtown Los Angeles had a primary lateral load resisting system of unreinforced infills. These buildings were constnucted early in the 1900s and typically had clay brick or clay tile infills. One notabje example is the City Hall building whict has steel framing with unreinforced clay tile infills. Groand motions in the downtown area were in the range of $0.15-0.20 \mathrm{~g}$ during the Northridge earthquake. This is typical of the level of excitation expected in many of the large moderate seismic zones in the eastern and central United States. Damage was noted in many of the iofills, primarily consisting of diagonal cracking or cracking along the infill boundary. Figures 8-9 show damage near building corners. Diagonal cracks are shown in Figures 10-11. 
Despite the damage, the buildings remained useable and stable after the earthquake. Seismic anatyses of unreinforced infil] buildings in moderate eastem and central United States zones have indicated diagonal cracking, and in some cases the initiation of comer crushing, could be expected (Flanagan et al., 1994). Thus, in a general qualitative sense, the behavior of the unreinforced infills was similar to that predicted by analyses.

The behavior of the infill buildings in downtown Los Angeles has significant impact on the eastern and central United States. A large building stock exists which has not been designed for any seismic load, but for which we know there is a risk of seismic activity. Many of these buildings only have a minimal lateral force resisting system apart from the unreinforced masonry infills. Adequately constructed infills should be capable not only of providing life safety functions, but should also in most cases have enough strength so that the buildings are useable after a moderate earthquake. Laboratory investigations have shown that repaired infills have close to the same strength as virgin infills (Flanagan, 1994), inplying that infill buildings damaged during maderate earthquakes can be economically repaired. Thus, many of the infill buildings in the large moderate hazard seismic zones in the central and eastern United States need not be retrofitted. They have sufficient seismic strength as is.

\section{OTHER RECENT OBSERVATIONS OF INFILL BEHAVIOR}

Several patterns of infill behavior are apparent when examining their behavior under seismic loading. Many aspects of infill behavior are quite beneficial. Jafarzadeh (1992) noted the reduction of intensity of damages of infilted frames in the Richter magnitude 7.61990 Iran earthquake. Other aspects of infill behavior may be detrimental. Two large infilled frame motels, jncluding one that had been open only 18 days, suffered some of the most serious damage during the 1993 Guam earthquake (Swan and Harris, 1993). Recent observations of infill behavior in seismic events is reviewed in the following.

Infills serve to stiffen structural framing, thus reducing the natural period of the structure. Typically the shortened period results in higher seismic forces. The additional stiffness and strength, though, can serve to limit seismic drift, keep the building in the elastic range, and more than compensate for the increased seismic forces (Buneall and Saatcioglu, 1994a), Miranda and Bertero (1989) suggested that pertaps the most important factor in the generally good performance of low-rise reinforced concrete frame structures in the 1985 Mexico City earthquake was the presence of masonry infills. The increased strength and stiffness generally kept the buildings in the elastic range. The shortened period also resulted in reduced inertial forces in the $1985 \mathrm{Mexico}$ City earthquake (Klingner et al., 1987), although this is not necessarily typical.

Similas observations of the beneficial perfomance of infills were made after the 1992 Egyptian earthquake (Adham, 1994; Elgamal et al., 1993). This earthquake generated maximum ground accelerations of approximately $0.20 \mathrm{~g}$. The intensity of shaking could be considered similar to what would be expected in moderate seismic zones of the eastern and central United States. Due to the soft soil conditions, the stiffening effects of the infills proved beneficial in this earthquake. Despite low-quality construction, and no consideration of seismic design, infiled frame buildings performed quite well. Damage was mainly due 
to special circumstances. For example, the one infilled frame building that collapsed was a 14 story butlding designed for 8 stories.

Typical in-plane behavior of infilled masonry structures is cracking around the infill perimeter, diagonal cracking of the infill, and finally compression failures along the diagonal. Often the compression failure will be in the loaded comers, and result in face shell spalling, and loss of masonry. Both in-plane corner crushing and diagonal tension failures of masonry infills have been observed after earthquakes (Malley, 1994). The failure of infills causes the lateral forces and energy to be shifted to the frame, and may result in substantial building damage or collapse (Amrtein et al., 1973; Adham. 1994). In the process of being darnaged, the infills, even if unreinforced, dissipate a significant amount of seismic input energy. This has in many cases prevented coltapse of the building (Stone et al., 1987). A detrimental side effect of the infill damage and faiture is that the debris can block exits and create a hazard around the exterior of the building (Bruneau and Saatcioglu, 1994a).

Infills provide a redundant path for both lateral and gravity loads. The top stories of a building in Guam shifted nine inches, shattering the ground floor columns, and leaving them unable to carry gravity loads. Part of the building was left supported by the masonry infills (Swan and Harris, 1993). Several buildings were observed in the 1992 Egypt earthquake where there was crushing of reinforced concrete corner coiumns. The masonry infill provided an alternate system for carrying part of the vertical loads after column crushing (Adham, 1994).

Since infills are generally not designed as structural elements, their effect is often ignored in the design phase. The placement of infills can lead to poor seismic configurations. Often infills are terminated at the lower level, causing a soft first story. This problem has been noted in severad earthquakes. Thiruvengadam and Wason (1992) and Mallick (1984) describe buildings whose first floor completely collapsed due to the absence of infills or other lateral bracing, while the upper stories remained intact and fell as a rigid body, with no member overstressed. There was evidence of large sway deflections in the first floor prior to collapse. Infills may atso be asymmetrically placed, leading to considerable torsion in the structure (Swan and Harris, 1993; Stone, et al., 1987; Saatcioglu and Bruneau, 1993).

Partial beight infills can be quite detrimental to the performance of framed structures. Partial height infills can result either from initial construction, such as a wall with windows at the top, or can result from corner coushing, and loss of the top part of the infill. Partial height inflls create short effective column heights which attract a high proportion of the load. The short columns often fail in shear, particulariy if constnucted of reinforced concrete (Berg and Hanson, 1973).

The 1992 Erzincan earthquake provided a good basis for observing infill behavior during a strong motion earthquake (Malley et al., 1993). Most of the commerciai building stock was reinforced concrete frames with unreinforced masonry infills. Most of the masonry was hollow clay tile, with a few building with clay brick and concrete masonry infills. The one strong motion instrument recorded peak accejerations of $0.40 \mathrm{~g}$ and $0.49 \mathrm{~g}$ in the horizontal direction, and $0.25 \mathrm{~g}$ in the vertical direction, with a 5-6 second duration of strong shaking (Malley, 1994). Typical problems with infills, such as soft first stories, and short effective 
column lengths from partial height infills were observed. In many cases, the infills were heavily damaged, but appeared to provide enough strength and ductility to perform life safety funckions. Two hoteis that collapsed were reported to have few infills and tall, open first stories.

The performance of hospitals during the 1992 Erzincan earthquake provides an interesting basis for the study of infills (Malley et al., 1993). The first floor of one wing of the Military Hospital which did not have infills collapsed. The upper four floors, which had infills, remaining intact. The adjacent wing, which had infills on the first floor as well as the other floors, remained standing. Sheas failures were observed in columns, indicating a significant contribution of the infills to the lateral resistance. At the Social Security hospital, a newer L-shaped wing completely collapsed. Torsion and force transfer problems at wide shallow beam connections contributed to the collapse. The original hospital suffered sever cracking to the longitudinal infills, but remained standing. At State Hospital, the newest building suffered little damage. The main building suffered severe damage to infills on the first floor, but remained standing. It was reported that this building suffered similar, but less severe, damage during the 1983 Erzurum earthquake and had been repaired. In summary, the infills were unable to provide sufficient seismic resistance for the hospitais to remain useable after the large earthquake. This severely hampered emergency medical care. The infills were able to prevent buildings from collapsing, thus providing life-safety functions and reducing the number of casualties.

Some of the most severe infill damage was experienced during the 1993 Guam earthquake (EERI, 1995). Although there were no ground motion records from this earthquake, maximum ground shaking was estimated to be between $0.15 \mathrm{~g}$ and $0.25 \mathrm{~g}$. Two major motels (12 story and 4 story) consisting of reinforced concrete frames with reinforced concrete masonry infills were damaged to the point that they were subsequently demolished. Infill masonry damage consisted of large diagonal cracking, spalling of masonry face shells, and collapse of entire paneis. In a smaller two-story stnucture, the concrete masonry facesheils of an infill spalled off leaving grout plugs hanging like icicles. Much of the damage is due to the infills, as they created poor seismic configurations. These include soft-stories where the infills are terminated, short effective column lengths from partial height infills, and torsion from the infill frame stiffness shifting the center of rigidity of the building. Infills in this earthquake appeared to do more harn than good. After creating problems due to their placement, the infiils did at least perform life safety functions. One interesting aspect that was not discussed in the reconnaissance report was the behavior of infills with openings. A photo from one of the motels appears to show an infill with a door opening on one side. Diagonal/shear cracking appears to be present consistent with that observed in laboratory tests (Dawe and Seah, 1989).

Experimental testing has indicated that most infills have significant out-of-plane capacity doe to arching (in-plane membrane forces) provided the boundary conditions are able to resist the in-plane thrust. Except for panels with high height to thickness ratios, infills shovld in general have acceptable out-of-plane behavior during seismic events. Very few out-of-plane infill fajlures have been reported during seismic events. For example, Thiruvengadam and Wason (1992) describe several buildings where unreinfored infills experienced diagonal cracking and "separation" (apparently cracking at the frame/infill interface) from the 
surrounding frame. However, in the three buildings described, no mention was made of outof-plane damage or failures, and no restrictions were made on the subsequent use of the buildings.

Widespread out-of-plane damage to "thin" unreinforced masonry infills was noted in the 1990 Iran earthquake (Mehrain, 1990). A building with light steel sections that reduced the wall span for out-of-plane bending performed better, as well as structures with "thick" infills. This appears to confirm the importance of the heightthickness parameter in developing outof-plane strength through arching.

The need for confinement of masonry infill panels was apparent in the 1992 Erzincan earthquake (Bruneau and Saatcioglu, 1994b; Malley, I994). Widespread out-of-plane failures of gable end walls above the main roof slab were observed, while the infilled masonry panels below would remain stable. Most of the out-of-plane failures were due to prior in-plane damage. Damage around the periphery of the infill would cause gaps between the infill and the bounding frame, leading to out-of-plane movements, and possibly panet fajlures (Saatcioglu and Bruneau, 1993). Hollow clay tiles oriented with cells perpendicular to the wall at the perimeter formed a weak plane. Upon in-plane failure, the remaining panel failed out-of-plane as a unit (Malley, 1994). In some cases, in-plane failures wotsld only cause partial out-of-plane failures, and a portion of the infill would remain intact (Bruneau and Saatcioglu, 1994b).

\section{CONCLUSIONS}

The response of masonry infilis during the Northridge earthquake was described. Several lowrise and midrise buildings near the epicenter experienced extreme ground shaking, but did not collapse, primarily due to the beneficial aspects of infilled frames. Near downtown Los Angeles, several highrise buildings were subjected to base excitation similar to that expected in moderate seismic zones of the central and eastern United States. These infill structures performed well, experiencing little darnage, and are expected to remain in use.

Infill performance in a variety of recent earthquakes was reviewed. In general, the positive attributes of infilled frame construction was demonstrated. Observations of infill peformance in the Northridge earthquake are consistent with those of other earthguakes and various experimental and analytical programs designed to determine the seismic response of infills.

\section{ACKNOWLEDGMENTS}

This work was sponsored by the National Science Foundation under tesearch grant number CMS-9416262. 


\section{REFERENCES}

Adham, S.A. (1994). Impact of Infilled Masonry Walls on the Response of Building in Moderate Seismic Zones." Proceedings from the NCEER Workshop on Seismic Response of Masonry Infills, National Center for Earthquake Engineaing_Research Report 94-0004, 2-23 to 2-29.

Amrhein, J.E., Hegemier, G., and Krisbnamoorty, G. (1973). "Report on the Nicaragua Earthquake of December 1972." Fifth Wortd Conference on Earthquake Engineering, 94108.

Berg, G.V., and Hanson, R.D. (1973). "Engineering Lessons Taught by Earthquakes. " Eifth World Conference on Earthquake Engineering, 82-91.

Bruneau, M., and Saatcioglu, M. (1994a). "Behavior of Unreinforced Masonry Structures during the 1992 Erzincan, Turkey, Earthquake." The Masonry Society Joumal, 12(2), 79-87.

Bruncau, M., and Saatcioglu, M. (1994b). "Behavior of Unreinforced Masonry Structures During the 1992 Erzincan, Turkey, Earthquake."Peocedings of the Fifth U.S. National Conference on Earthquake Engineering, Clicago, II, 409-418.

Dawe, J.L., and Seah, C.K. (1989). "Behaviour of Masonry Infilled Steel Frames." Canadian Journal of Civil Engineering, 16(6), 865-876.

EERI (1995). "Guam Earthquake of August 8, 1993 Reconnaissance Report." Earthquake Svectra, Supplement B to Volume 11, April, 1995.

Elgamal, A.W., Amer, M., Adalier, K., and Abul-Fadl, A. (1993). "Engineering Aspects of the October 12, 1992 Egyptian Earthquake. "National Center for Earthquake Engineering Research Report 93-0018.

Flanagan, R.D. (1994). "Behavior of Structural Clay Tile Infilled Frames." Dissertation presented for the Doctor of Philosophy degree, The University of Tennessee, Knoxville, TN.

Flanagan, R.D., Tenbus, M.A., and Bennett, R.M. (1994). "Seismic Evaluation of Industrial Facilities with Unreinforced Structural Clay Tile Infills." Proceedings. Fifth U.S. National Conference on Earthiquake Engineering, Chicago, IL, 365-374.

Jafarzadeh, F. (1992). "Civil Engineering Features of Damage on June 20, 1990 ManjilRudbar Earthquake, Iran." Tenth World Conference on Eartbquake Engineering, Madrid, Spain.

Klingner, R.E., Beiner, R.J., and Amthein, J.E. (1987). "Perfornance of Masonry Structures in the Mexican Earthquake of September 19, 1985." Fourth North American Masonry Conference, $70-1$ to $70-14$. 
Malley, J.O. (1994). "Response of Multi-Story Concrete Ftame Hollow Clay Tile Infill Wall Buildings in the March 13, 1992 Erzincan, Turkey Earthquake: Implications to U.S. Construction Practice."Proceedings of the Fifth U.S. National Conference on Earthquake Engineering, Chicago, IL, 397-407.

Malley, J.O., Celebi, M., Bruneau, M. Saatciogiu, M., Erdik, M., and Gulkan, P. (1993). "Erzincan, Turkey Earthquake of March 13, 1992 Reconnaissance Report - Buildings." Earhquake Spectra, Supplement to Vol. 9, 53-85.

Mallick, D.V., (1984). "Engineering Studies of Building Response During El Asnam Earthquake of October 10,1980." Proceedings of the Eight World Conference on Earthquake Engineering, 4, 783-790.

Mehrain, M. (1990). "Reconnaissance Report on the Northern Iran Earthquake of June 21, 1990." National_Center for Earthonake. Engineering Research Report 90-0017.

Miranda, E, and Bertero, V.V. (1989). "The Mexico Earthquake of September 19, 1985 Performance of Low-Rise Buildings in Mexico City." Earthquake Spectra, 5(1), 121-143.

Saatcioglu, M., and Bruneau, M. (1993). "Performance of Structures During the 1992 Erzincan Earthquake." Canadian Joumal of Civil Engineering, 20(2), 305-325.

Stone, W.C., Yoket, F.Y., Celebi, M., Hanks, T., and Leyendecker, E.V. (1987). "Engintering Aspects of the September 19, 1985 Mexico Earthquake." NiBS Hivildinq Science Series 165.

Swan, S.W., and Harris, S.K. (1993). "The Island of Guam Earthquake of August 8, 1993," National Center for Earthquake Engineering Research Report 93-0017.

The Masonry Society (1994). "Performance of Masonry Structures in the Northridge, California Earthquake of January 17, 1994." A report by the investigating disasters reconnaissance team.

Thiruvengadam, V., and Wason, J.C. (1992). "Post Earthquake Damage Studies on the Performance of Buildings During Bihar (India)-Nepal Earthquake on 21st August 1988." Proceedings, Tenth World Conference on Eanthquake Engineering, 67-72.

Wald, D,J., and Heaton, T.H. (1994). "A dislocation model of the 1994 Northridge, California earthquake determiłed from strong ground motions." U.S. Geologicai Suryey Open-Eile_Report 94-278.

Yanev, B., and McNiven, H.D. (1985). "An Experimental Program for Studying the Dynamic Response of a Steel Frame with a Variety of Infill Partitions", Earthulake Engineering Research Center Report UCB/EERC-85/16. 


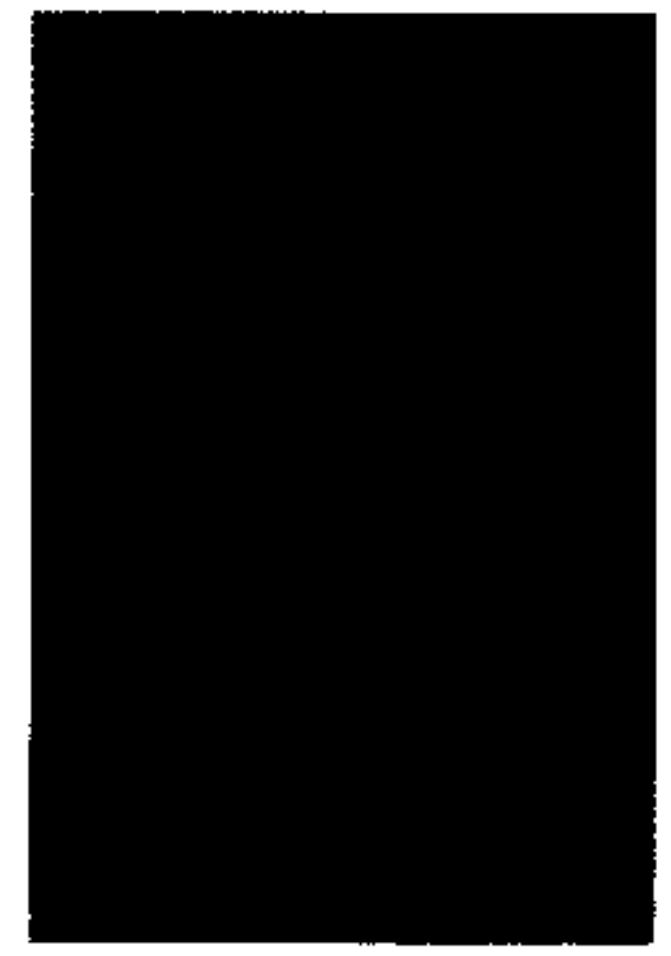

Figure 1: Sepulveda VA Hospita] Building 40

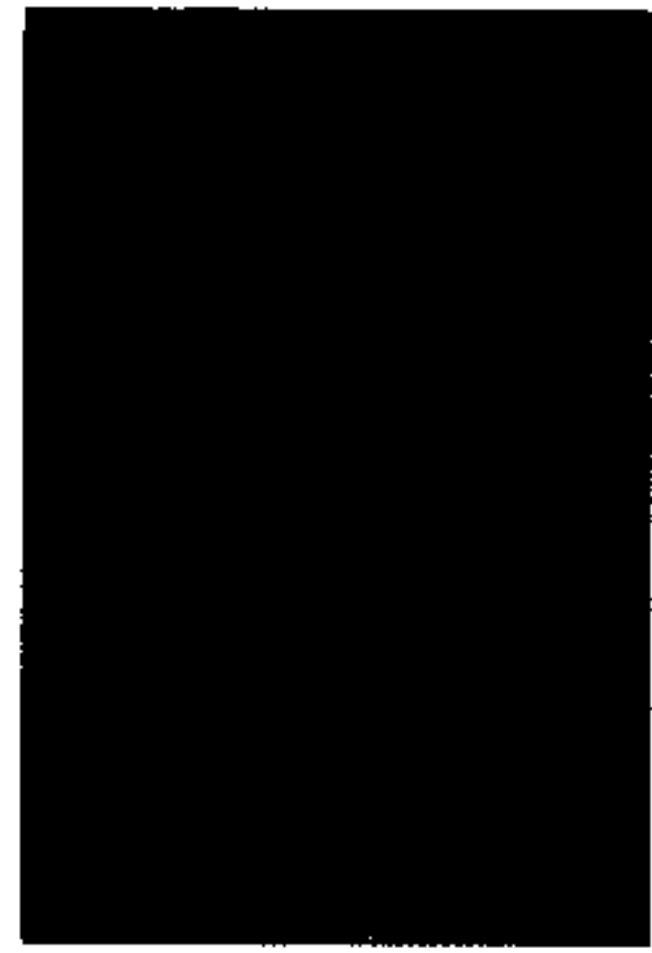

Figure 2: Column Reinforcement

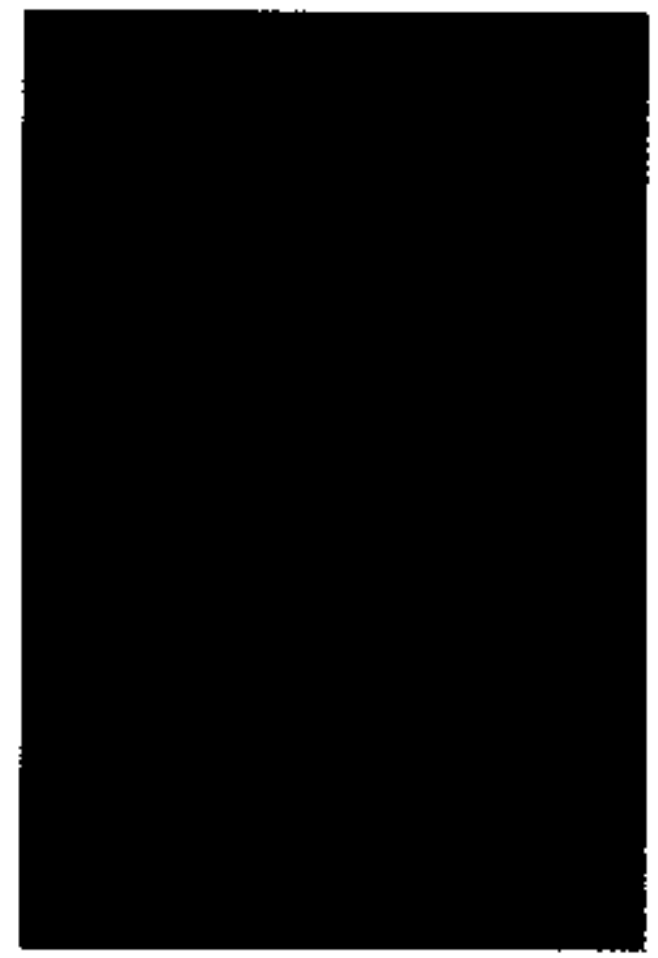

Figtre 3: Infit] Grout Core 
Figure 4: Parking Garage

Figure S: Isolated Panel

Figure 6: Parking Garage

Figure 7: Infill Contact

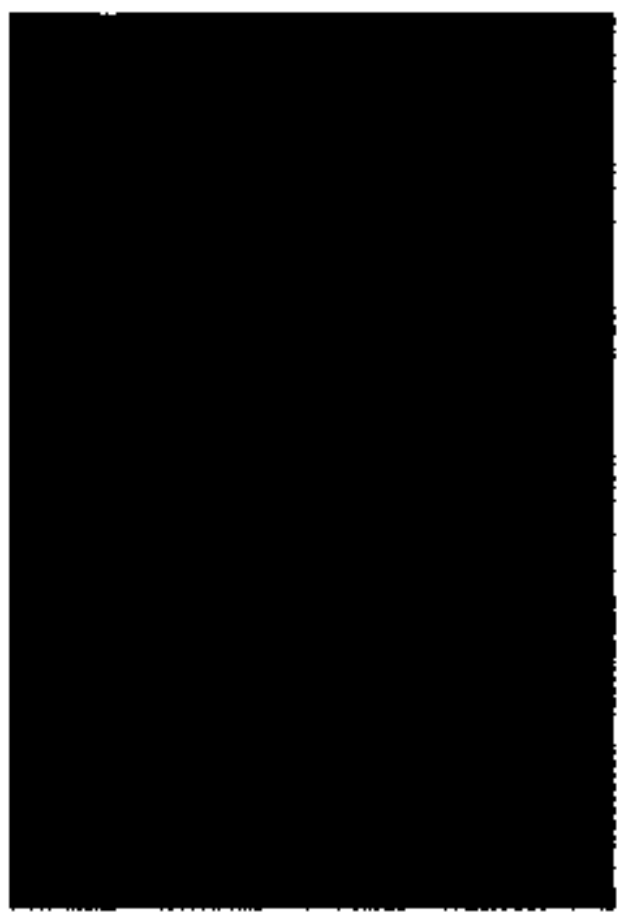

Figure 8: Los Angeles Buitding

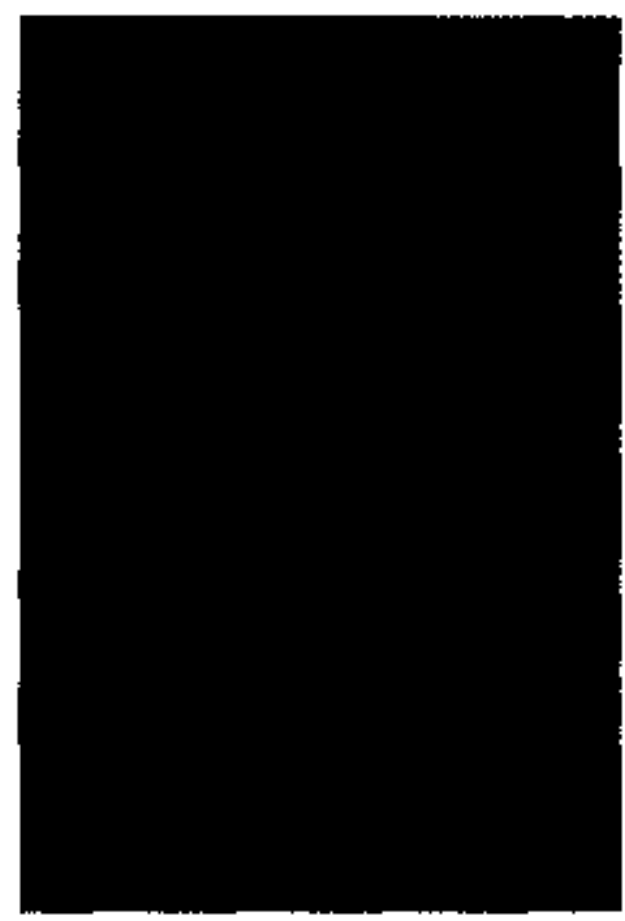

Figure 9: Pasadena Building

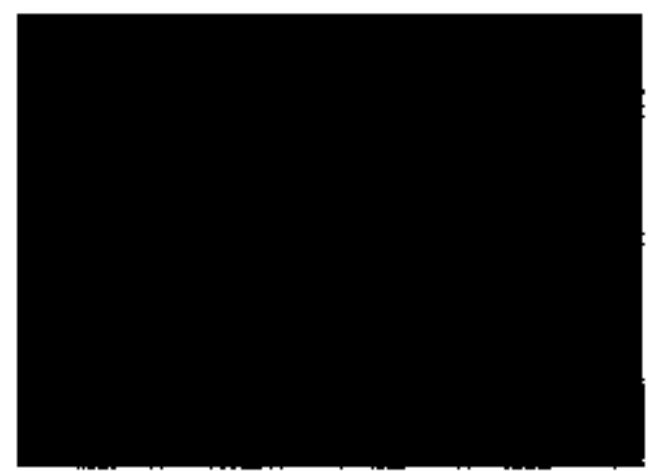


Figure 10: Pomona Building

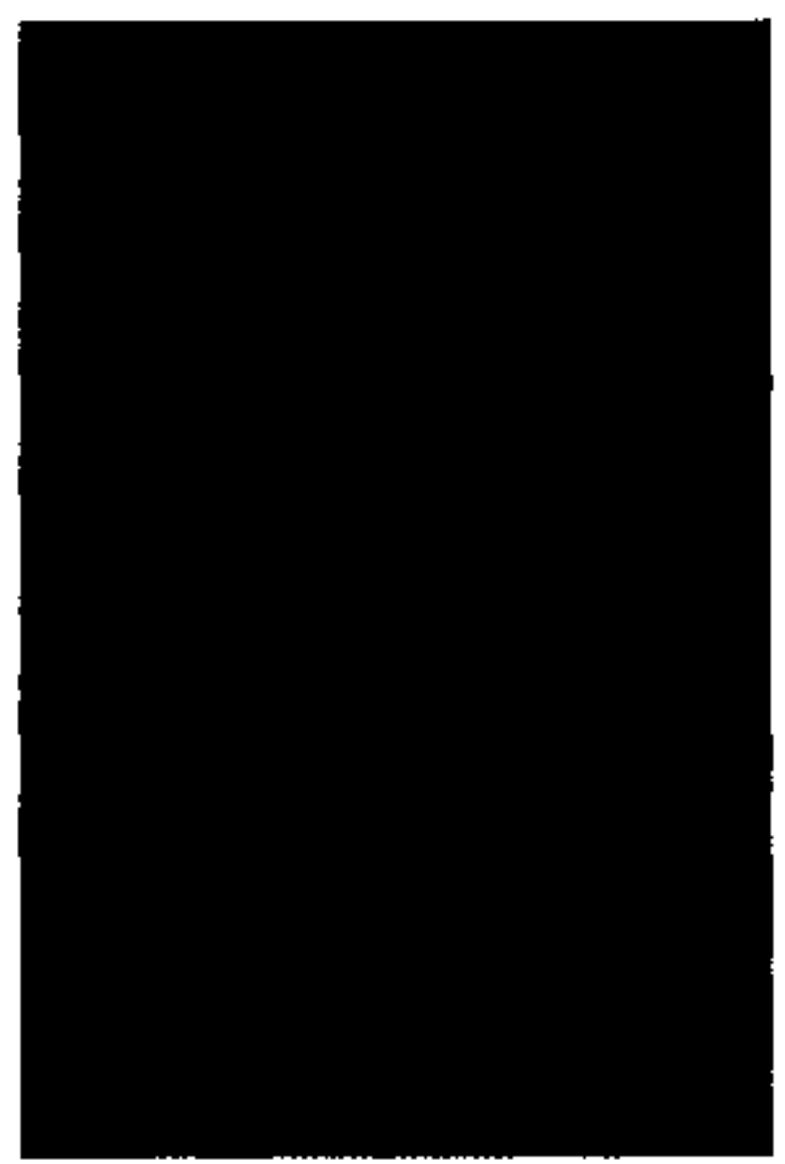

Figure 11: Pasadena Building 
Distribution:

R. M. Bennett

D. R. Denton

R. D. Ftanagan

K. E. Fricke

R. J. Hunt

R. J. Kroon

A. K. Lee/DOE OSTI (2)

N. E. Stone

M. A. Tenbus

CAE Files

Y*12 Central Files 